\title{
QUANTITATIVE FRACTIONATION OF COMPONENT PROTEINS OF HUMAN SERUM WITH CATIONIC DETERGENTS ${ }^{1}$
}

\author{
BY RALPH F. JACOX 2 \\ (From the Department of Medicine, University of Rochester School of Medicine and Dentistry, \\ Rochester, New York)
}

(Submitted for publication February 9, 1953; accepted April 2, 1953)

In a preceding report (1) it was shown that variations in turbidity result when a cationic detergent such as octadecyl dimethyl benzyl ammonium chloride (Octab) ${ }^{3}$ is added to serum diluted in a collidine buffer of $\mathrm{pH}$ 6.8. These variations were found to be related to protein alterations resulting from acute infections. In acute rheumatic fever, for example (2), serum turbidity with the cationic detergent was greatest during the acute phase of the infection, and during subsidence of rheumatic activity a decreased turbidity resulted.

The present investigation is an extension of a study of the reaction of cationic detergents with different serum protein fractions. It will be shown that a quantitative assay of the alpha globulins, total globulins and the total protein fraction can be made. From these determinations it is then possible to calculate the concentration of albumin and the beta and gamma globulin fractions. This report describes the techniques utilized to produce differential protein precipitation with octadecyl dimethyl benzyl ammonium chloride. Protein assays of sera by Tiselius electrophoresis have been made. Results of the electrophoretic and detergent assays are compared to establish the accuracy of the latter method.

\section{METHODS}

The possibility that differentiation of the component proteins of human serum might be accomplished became evident in experiments wherein increasing amounts of diluted $\mathrm{NaOH}$ were added to a mixture of diluted serum and a cationic detergent. In such a system there is little or no precipitation when the $\mathrm{pH}$ is 4.0. As the $\mathrm{pH}$ is slowly increased, there are three distinct increments of

\footnotetext{
1 Research carried out under a grant for the study of rheumatic fever from the Masonic Foundation for Medical Research and Human Welfare.

2 Assistant Professor of Medicine, University of Rochester School of Medicine and Dentistry.

${ }^{3}$ All of the cationic detergents utilized were obtained through the generosity of Mr. Wellington Rounds, Fairfield Laboratories, Plainfield, New Jersey.
}

density. Between these increments there are intervening plateaus where there is little change in density associated with slight increase in $\mathrm{pH}$. These plateaus develop at $\mathrm{pH}$ 7.0 to $7.5, \mathrm{pH} 9.5$ to 10.0 and $\mathrm{pH} 11.5$ to 12.0 . When relatively homogeneous proteins such as fraction IV-1 (containing mostly alpha 1 and alpha 2 globulin), gamma globulin and albumin are employed, it is observed that fraction IV-1 reacts with a cationic detergent at $\mathrm{pH} 5.8$ to 7.0 to form considerable turbidity. Gamma globulin, however, is not reactive in this range of $\mathrm{pH}$ provided the protein concentration is below $20 \mathrm{mg}$. per $\mathrm{ml}$. This protein forms turbidity with a cationic detergent at $\mathrm{pH} 7.5$ to 9.8. Finally, albumin in a concentration less than $20 \mathrm{mg}$. per $\mathrm{ml}$. is not reactive with a cationic detergent until $\mathrm{pH}$ 10.0 is employed. As the $\mathrm{pH}$ is increased to 11.0 , a sharp increment of turbidity results and at $\mathrm{pH} 12.0$ maximal precipitation results. If sufficient cationic detergent is added to concentrated solutions of albumin or gamma globulin, the effect of $\mathrm{pH}$ is not as evident and these proteins precipitate at lower $\mathrm{pH}$ levels.

It will also be seen later that $\mathrm{NaCl}$ produces an effect on precipitation of the various protein components of human sera. Thus by proper choice of buffers, $\mathrm{NaCl}$ concentration, concentration of protein and a cationic detergent, a quantitative assay of the various components might be accomplished.

Preparation of buffers: A. For $p H$ 6.65-A $0.05 \mathrm{M}$ $2,4,6$ trimethyl pyridine (collidine) solution of $\mathrm{pH} 6.65$ is prepared (3). To this is added sufficient $\mathrm{NaCl}$ to make the concentration of the latter $0.08 \mathrm{M}$. The $\mathrm{pH}$ is again determined on a glass electrode $\mathrm{pH}$ meter and is redetermined each day prior to use. If a variation of more than \pm 0.05 $\mathrm{pH}$ units occurs, the $\mathrm{pH}$ is readjusted by addition of $0.1 \mathrm{~N}$ $\mathrm{HCl}$, or a new buffer is prepared. B. For $\mathrm{pH} 9.6-\mathrm{A} 0.05$ $M$ glycine-Na glycine buffer is prepared and adjusted to a $\mathrm{pH}$ of 9.6. To this is added sufficient $\mathrm{NaCl}$ to make a final concentration of $\mathrm{NaCl}$ of $0.08 \mathrm{M}$. Prior to use, the $\mathrm{pH}$ of this buffer is determined on a glass electrode $\mathrm{pH}$ meter and readjusted if necessary. C. For $p H$ 12.0-A solution containing $0.05 \mathrm{M} \mathrm{NaOH}$ and $0.4 \mathrm{NaCl}$ is prepared. The $\mathrm{pH}$ of this solution varies between 11.9 to 12.4. On standing, the $\mathrm{pH}$ may fall below 11.9 and a fresh solution must then be prepared.5

\footnotetext{
+ Obtained from Eastman Kodak Co., Rochester, New York.

- The exact $\mathrm{pH}$ of this solution cannot be determined with a glass electrode because the high sodium concentration makes the electrode insensitive to a $\mathrm{pH}$ over 9.0.
} 
Preparation of the detergent solution: One and 0.1 percent solutions of octadecyl dimethyl benzyl ammonium chloride (Octab) are made in distilled water. On standing in the cold the Octab may precipitate from solution. Prior to use, gentle warming of the solution will redissolve the Octab, and the solution will clear.

Preparation of the protein fractions and standard curves: Three human protein fractions, ${ }^{\circ}$ IV-1, II and V, were used to make standard curves for the alpha globulins, total globulin and albumin respectively. These fractions were obtained from the Squibb Laboratories, where they had been prepared by the Cohn fractionation technique. Fractions II and V were electrophoretically homogeneous. Fraction IV-1 contained 74 percent alpha 1 and alpha 2 and 26 percent albumin by electrophoretic analysis.

Fraction IV-1 is readily soluble at 4 percent concentration in 0.9 percent $\mathrm{NaCl}$ solution, to form an opalescent solution. After centrifugation only a minute amount of precipitate is removed. The supernatant solution is assayed for total nitrogen concentration by the Kjeldhal method ( 73 percent by weight of fraction IV-1 was protein material). In calculating the concentration of the alpha globulins, 74 percent of the Kjeldhal protein value is used.

Similar 4 percent solutions of fraction II and V are prepared. Since these solutions are homogeneous by electrophoresis, 100 percent of the Kjeldhal proteins value is used as the concentration of gamma globulin and albumin respectively.

- The protein fractions were obtained from Dr. J. N. Ashworth, E. R. Squibb \& Sons, Biological and Chemical Laboratories, New Brunswick, New Jersey.
Standard curve for alpha 1 and alpha 2 globulins: The 4 percent solution of fraction IV-1 assayed by the Kjeldhal method is diluted 1:100 with collidine buffer of $\mathrm{pH} 6.65$. Aliquots of this fraction, containing between 0.05 to 0.5 mg. of alpha 1 and alpha 2 globulins, are then accurately measured into $15 \times 145 \mathrm{~mm}$. colorimeter tubes. Sufficient buffer to bring the volume to $9.0 \mathrm{ml}$. is then added. To this solution, $1.0 \mathrm{ml}$. of 0.1 percent Octab solution is added and the tubes mixed immediately by inversion. The turbidity which develops is read on a Lumetron photoelectric colorimeter using a 440 filter. Maximal turbidity usually develops after 12 to 15 minutes. After 20 minutes, the density of the solution slowly decreases.

The optical density, corresponding to the calculated concentration of the alpha 1 and alpha 2 globulins, is then plotted for each determination as shown in Figure 1.

Standard curve for total globulin concentration: A 1:100 dilution of a stock solution of fraction II is made in the glycine buffer of $\mathrm{pH} 9.6$ so that each millilitre contains a known concentration within a range of 0.35 to $0.45 \mathrm{mg}$. per $\mathrm{ml}$. Aliquots of this solution varying in protein concentration from 0.05 to $0.8 \mathrm{mg}$. per $\mathrm{ml}$. are added to separate colorimeter tubes. To these solutions sufficient glycine buffer is added to bring the volume to 9.6 $\mathrm{ml}$. Four tenths millilitre of 1.0 percent Octab is added and mixed with the solution by inversion of the tubes. Density is then read after 10 to 15 minutes as described above. The optical density for each calculated concentration of gamma globulin is then plotted as shown in Figure 1.

Fraction IV-1 can be similarly made up in glycine buffer and used to make a standard curve for the total globulin concentration. The slope of the curves for fraction IV-1

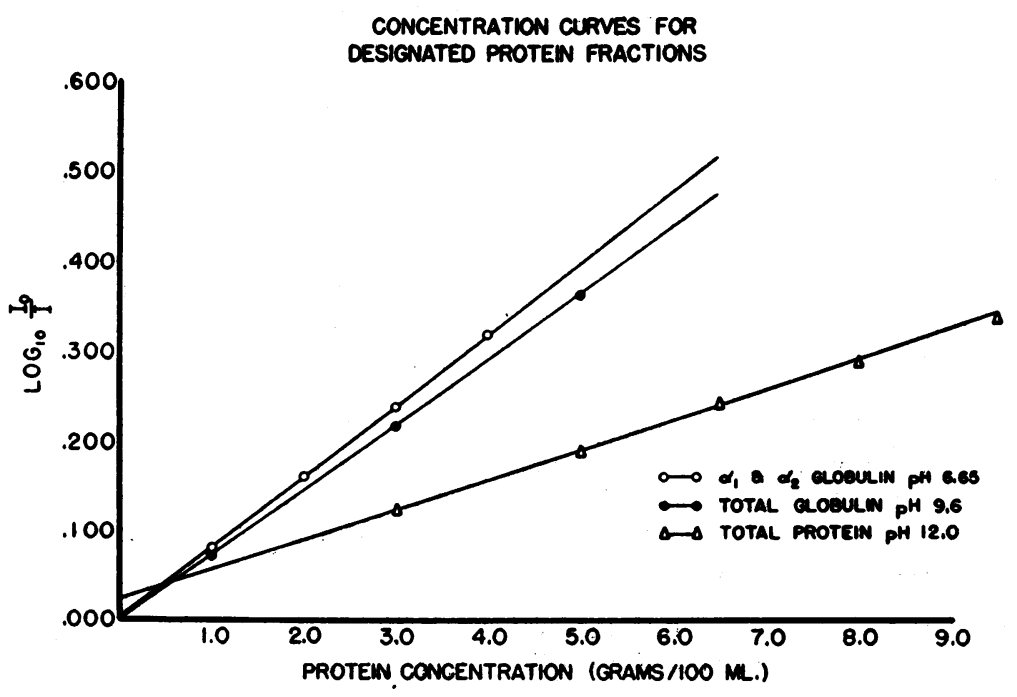

Fig. 1

Standard curves for each protein fraction for the designated $\mathrm{pH}$ are shown. The protein concentration is corrected for dilution so that direct reading of an unknown sample can be made. Thus the globulins are $1 / 100$ th and the total protein concentration is $1 / 1000$ th of the abscissa value shown. 
and II is identical. However, as seen in Table I, there is evidence that fraction IV-1, in addition to alpha 1 and alpha 2 globulins, contains an additional small amount of protein reacting at $\mathrm{pH} 9.6$ but not at $\mathrm{pH} 6.65$.

Standard curve for total protein concentration: Albu$\min$ is used to prepare a standard curve for assay of the total protein concentration. Fraction IV-1, II or whole serum of known protein concentration is suitable and will produce identical results. A 4 to 5 percent solution of albumin previously assayed by the Kjeldhal method is diluted $1: 100$ in the $\mathrm{NaOH}-\mathrm{NaCl}$ solution. Aliquots containing 0.04 to $0.08 \mathrm{mg}$. of protein are pipetted into colorimeter tubes. Sufficient $0.05 \mathrm{M} \mathrm{NaOH}-0.4 \mathrm{M} \mathrm{NaCl}$ is added to bring the volume to $9.6 \mathrm{ml}$. Four tenths millilitre of 1.0 percent Octab is added and mixed by inversion of the tubes. Density is then read on the colorimeter after 10 to 15 minutes until maximal density is determined. The optical density for each calculated concentration of albumin or other protein solution is then plotted as shown in Figure 1.

The Lumetron model 402-E colorimeter with filter $M$ 440 has been found to produce a steep slope with small increments of density in solutions of protein combined with Octab. Other colorimeters such as the Beckman, Coleman, Evelyn and Klett do not measure such changes as readily, in that slopes such as depicted in Figure 1 have 2 lessened density gradient with corresponding increases in protein concentration. This difference in instruments is explained by the fact that the Lumetron is designed so that the cuvette is placed about $5 \mathrm{~cm}$. from the photoelectric cell. With this arrangement much of the scattered light does not impinge on the photocell and thus a closer measure of transmission is obtained. In the other instruments mentioned, where the cuvette is placed close to the photocell, much of the scattered light impinges on the photocell, thus decreasing the sensitivity of measurement of turbidity.

Recently, a nephelometric attachment has been used in the Lumetron 402-E colorimeter. Results obtained by this technique indicate that changes in density caused by the reaction of Octab with proteins may be measured with a two to threefold increase in sensitivity over that obtained by the method described above.

A nephelometric technique, or the use of a colorimeter which is designed so that scattered light does not reach the photocell, is necessary, therefore, for an accurate assay of the turbidity developing in the interaction of proteins and cationic detergents.

Assay of mixed protein solutions: An accurately measured amount of serum $(0.0500$ to $0.1200 \mathrm{ml}$.) obtained from clotted blood is measured into a test tube. A micropipette has been found to be most suitable. (These may be prepared from $5 \mathrm{~mm}$. glass tubing or they can be obtained from MISCO, Microchemical Specialties Co., Berkeley, California.) Sufficient $0.08 \mathrm{M} \mathrm{NaCl}$ solution is added to produce a 1:100 dilution of the serum. To assay the alpha 1 and alpha 2 globulin concentration, $1.0 \mathrm{ml}$. of the diluted serum is pipetted into a test tube. Eight millilitres of collidine buffer solution ( $\mathrm{pH} 6.65)$ are added. One millilitre of 0.1 percent Octab is then added and mixed with the protein and buffer solution by inversion of the tube. After standing for 10 to 12 minutes the optical density is determined. This reading is repeated until maximal density is recorded. By interpolation from the previously determined standard curve for the alpha 1 and alpha 2 globulins, the concentration of the alpha globulins is calculated.

Total globulin is assayed by adding $1.0 \mathrm{ml}$. of diluted serum to a test tube. To this is added $8.6 \mathrm{ml}$. of glycine buffer of $\mathrm{pH} 9.6$. Then $0.4 \mathrm{ml}$. of 1.0 percent Octab is added to the solution and mixed by inversion of the tube. After maximal density has developed (10 to 15 minutes) the optical density is recorded. By interpolation from the fraction II standard curve the amount of total globulin is calculated.

The assay of total protein concentration is made by addition of $0.1 \mathrm{ml}$. of the diluted serum to a colorimeter tube. A standardized $0.2 \mathrm{ml}$. pipette with a curved tip measures accurately this volume of diluted serum. Nine and one half millilitres of $0.05 \mathrm{M} \mathrm{NaOH}$ to $0.4 \mathrm{M} \mathrm{NaCl}$ solution are added to the tube and then $0.4 \mathrm{ml}$. of 1.0 percent Octab is pipetted into the mixture. After mixing of these solutions by inversion, density is read on the colorimeter after 10 to 15 minutes. The maximal density is determined and then the total protein concentration is calculated by interpolation from the standard curve.

In most sera, the protein concentration for each fraction assayed is sufficient to cause variation of density ranging from 85 percent to 45 percent transmission of light. In sera where the total globulin concentration or total protein concentration is excessive, then densities exceeding these limits may result. In such instances, the amount of diluted serum used in the test is decreased by a factor of one half. The result obtained from the standard curve is then multiplied by two. In sera with a low concentration of total protein, a more accurate assay results when $0.2 \mathrm{ml}$. of diluted serum is added to the colorimeter tube. The result obtained from the standard curve is then divided by two.

\section{EXPERIMENTAL RESULTS}

It has been stated above that differentiation of the alpha globulins, gamma globulin and albumin can be made, provided the protein concentration, $\mathrm{pH}$ and $\mathrm{NaCl}$ concentration are suitably regulated. Thus albumin requires a high $\mathrm{pH}$ before precipitation occurs, while gamma globulin and the alpha globulins precipitate at intermediate and low $\mathrm{pHs}$ respectively. At an intermediate $\mathrm{pH}$ (9.6), the alpha globulins combine with Octab in a similar manner to gamma globulin so that a summation of the total globulin fraction results. At a high $\mathrm{pH}$ (12.0) all of the component proteins react with Octab and a summation of all proteins results. 
In this type of investigation, preparations of "pure" proteins are desirable. Reactions II and V reasonably fulfill this requirement, but it is recognized that even these fractions consist of heterogeneous proteins. Fraction IV-1 is recognized to be sufficiently heterogeneous to introduce error into the quantitative measurements described. An homogeneous preparation of beta globulins has not been available. However, a preparation of fraction III obtained from the Squibb Laboratories is found to react in many respects like fraction IV-1. Since fraction III is not readily soluble in 0.9 percent $\mathrm{NaCl}$ and in solution is sufficiently turbid to prohibit electrophoretic assay, no information is available concerning the constituent proteins of the particular fraction. Fraction IV-4 obtained from the same laboratories was studied. The beta globulins contained in it do not react with the cationic detergent at $\mathrm{pH} 6.65$ but behave like gamma globulin.

After comparative studies of sera assayed by electrophoretic and detergent techniques had been carried out (Figures 6 through 8), it was evident that most beta globulins react with a cationic detergent in the same manner as the gamma globulins. This supposition is not always valid as indicated in an investigation of serum from a patient with sarcoidosis of the liver. This lesion had caused intra-hepatic obstruction. By electrophoresis, this patient's serum contained a large beta anomaly in the gamma peak of the descending boundary similar to that described by Zeldis and Alling in patient J. M., page 423 (4). Turbidimetric assay of this serum with Octab revealed an alpha globulin concentration of $2.4 \mathrm{gm}$. and the beta and gamma fraction was $1.4 \mathrm{gm}$. By electrophoretic measurement, the concentration of the alpha globulins was $1.40 \mathrm{gm}$. while the beta and gamma concentration was $4.0 \mathrm{gm}$. (1.58 beta and 2.46 gamma). Thus a striking discrepancy is found not only within each of the fractions but in the total globulin concentration. The difference in the total globulin concentration $(3.8 \mathrm{gm}$. by detergent assay vs. $5.4 \mathrm{gm}$. by electrophoretic assay) may be attributable to measurement by electrophoresis of a high lipid concentration. The discrepancy in the assay of the alpha globulins may be explained by the possibility that the abnormal beta globulin found in this serum reacts with the cationic detergent in a manner similar to the alpha globulins.

Effect of $\mathrm{NaCl}$ on reaction of Octab with proteins. In a previous report (1) it was shown that the precipitation of serum protein (alpha 1

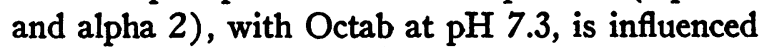
by salt concentration. The effect of $\mathrm{NaCl}$ on the precipitation of the alpha globulins, gamma globulin and albumin by Octab has been investigated utilizing $\mathrm{pH}$ values of 9.6 and 12.0 (Figures 2 and 3). At $\mathrm{pH} 9.6$ it will be observed that Frac-

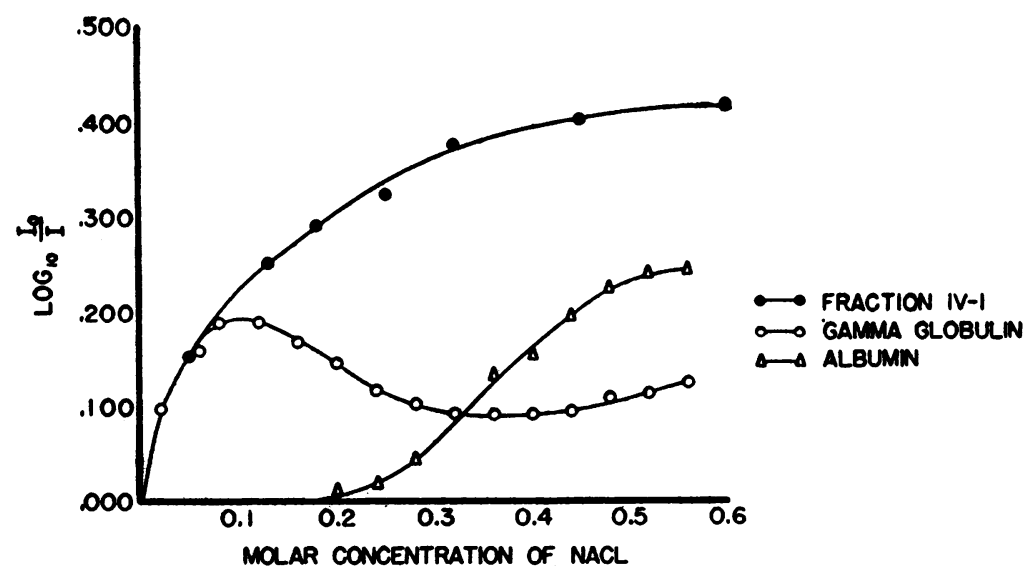

FIG. 2

The effect of sodium chloride concentration at $\mathrm{pH} 9.6$ is shown for each of three protein fractions studied. 
tion IV-1 fails to precipitate with Octab if no $\mathrm{NaCl}$ is present. An increasing turbidity develops and reaches a maximum in a concentration of $0.4 \mathrm{M}$ $\mathrm{NaCl}$ in glycine buffer. Fraction II (gamma globulin) develops maximal density with Octab when the $\mathrm{NaCl}$ concentration is 0.08 to $0.12 \mathrm{M}$. When the $\mathrm{NaCl}$ is increased beyond these limits then the density decreases. In the investigations of albumin it is observed that no turbidity develops at $\mathrm{pH} 9.6$ until the $\mathrm{NaCl}$ concentration reaches $0.25 \mathrm{M}$. With the concentration of $\mathrm{NaCl}$ increased to $0.5 \mathrm{M}$, a maximal density results. Since the detergent precipitates in a $0.7 \mathrm{M}$ concentration of $\mathrm{NaCl}$, no higher salt concentrations than $0.5 \mathrm{M}$ were used in this study.

It is seen from Figure 2 that at $\mathrm{pH} 9.6$, alpha 1 and alpha 2 globulins and gamma globulin react similarly if the $\mathrm{NaCl}$ concentration is 0.08 to $0.12 \mathrm{M}$. In this range, albumin is not precipitated. If the $\mathrm{NaCl}$ concentration is increased the precipitation of the alpha 1 and alpha 2 globulins is enhanced while the precipitation of gamma globulin is depressed. Finally, with higher concentrations of $\mathrm{NaCl}$, albumin begins to precipitate. For purposes of assay of the total globulins in a mixture of proteins, a $\mathrm{NaCl}$ concentration of 0.08 to $0.12 \mathrm{M}$ is optimal.

If these fractions are investigated in a system where the $\mathrm{pH}$ is 12.0 , a different reaction occurs (Figure 3). It will be seen that $\mathrm{NaCl}$ enhances the precipitation of all three fractions to about the same degree. If no $\mathrm{NaCl}$ is present, no precipitation occurs. With each increment of $\mathrm{NaCl}$ to a concentration of $0.1 \mathrm{M}$ there is a striking increase in density. Beyond this concentration of $\mathrm{NaCl}$, a less steep slope of increasing density develops.

Effect of cationic detergent concentration on protein precipitation. A limitation in the study of the effect of anionic detergents on protein precipitation is imposed by a narrow range of precipitation effect dependent on an optimal protein: detergent ratio (5). This effect is not observed with the cationic detergent Octab when it reacts with albumin, alpha 1 and alpha 2 globulins or gamma globulin at $\mathrm{pH} 9.6$ or 12.0 . If the protein concentration is between 0.4 to $0.9 \mathrm{mg}$. per $\mathrm{ml}$., at least $3 \mathrm{mg}$. of Octab is required. If greater amounts of detergent are added no change in turbidity results.

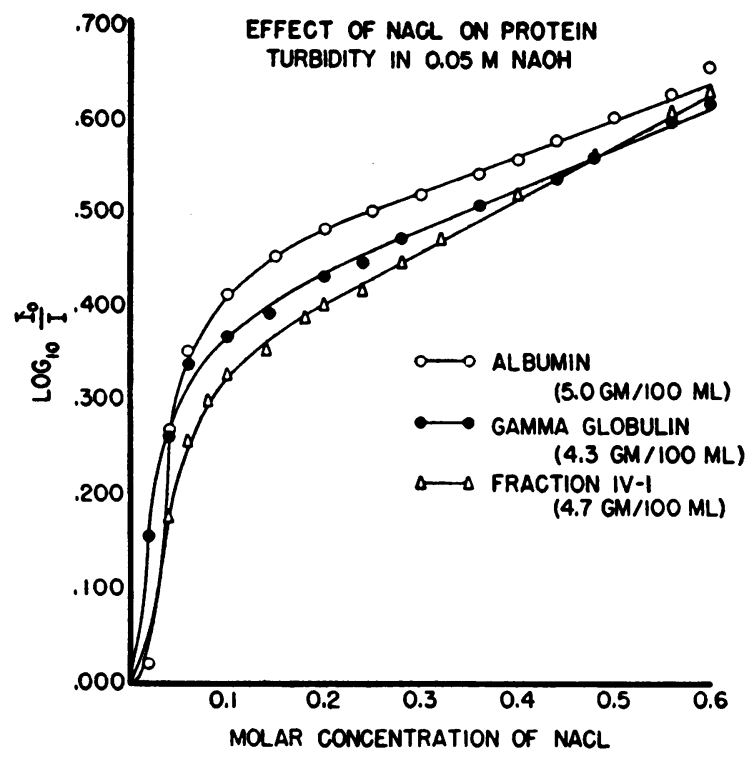

FIG. 3

The effect of sodium chloride concentration at $\mathrm{pH} 12.0$ is shown for each of three protein fractions investigated.

Some influence of the protein to detergent ratio is found however, at $\mathrm{pH} 6.65$, the range employed for alpha 1 and alpha 2 globulin assay. Fraction IV-1, alone and with albumin or gamma globulin added, was prepared in a buffer of $\mathrm{pH} 6.65$ and $0.08 \mathrm{M} \mathrm{NaCl}$ concentration. Different amounts of Octab were then added. The data in Figure 4 reveal that the optimal concentration of detergent for the concentration of fraction IV-1 employed is $0.5 \mathrm{mg}$. per $10 \mathrm{ml}$. of reacting system (buffer, diluted protein and detergent solution). If the Octab is increased to $1.0 \mathrm{mg}$. there is a decrease in precipitation. A similar result is obtained in a system which contains fraction IV-1 and albumin. When the combined fraction IV-1 and gamma globulin is added to Octab, however, the decrease in density resulting from addition of $1.0 \mathrm{mg}$. of Octab is not as great. When Octab is added to a final concentration of $8.0 \mathrm{mg}$., a considerable decrease in protein precipitation results not only for fraction IV-1 and gamma together but in all the combinations employed.

The sparing effect of gamma globulin on fraction IV-1 precipitation may be related to its ability to combine partially with the detergent at $\mathrm{pH} 6.65$ without being precipitated. Thus the optimal ratio of detergent and the alpha 1 and alpha 2 globulins is maintained. In studies to be described later, 


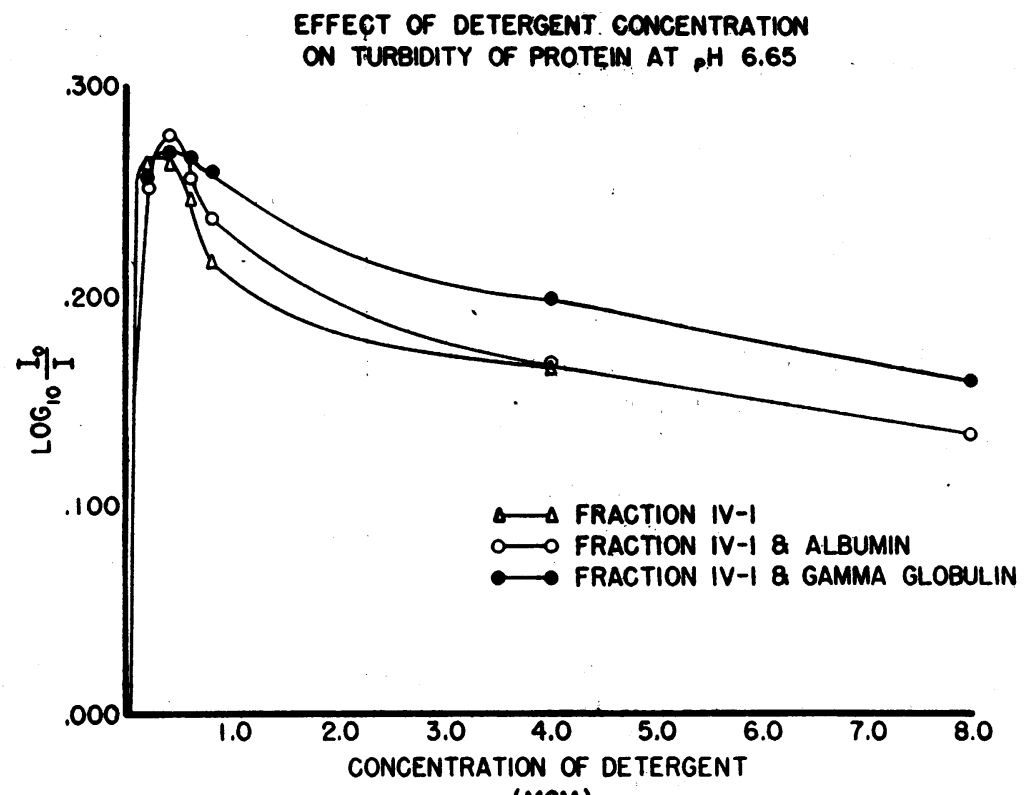

(MGM)

Fig. 4

The influence of cationic detergent (Octab) concentration on combinations of proteins with alpha 1 and alpha 2 globulins (fraction IV-1) is shown.

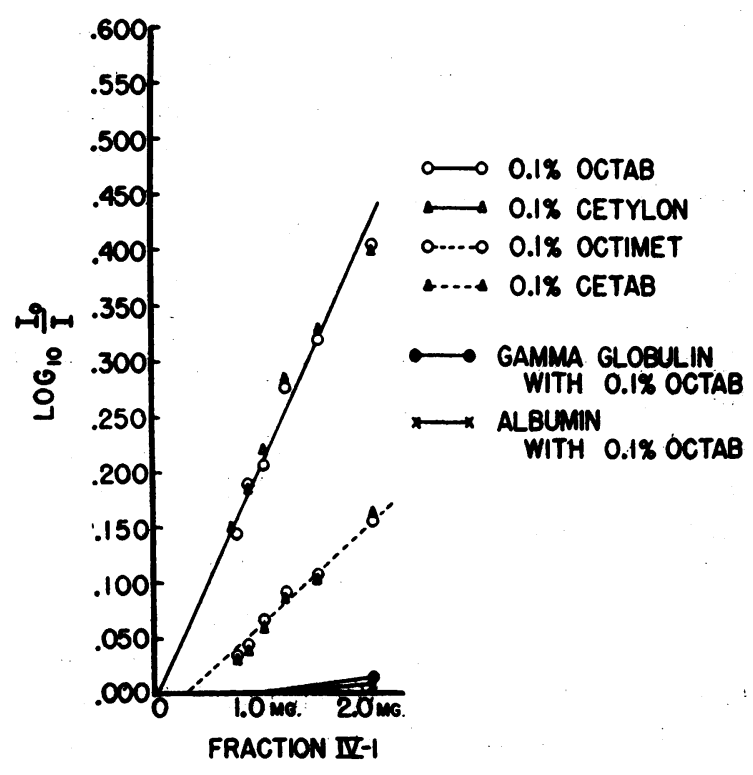

PROTEIN CONCENTRATION

(MG./ML.)

FIG. 5

The effect of different cationic detergents reacting at pH 7.3 in a $0.08 \mathrm{M} \mathrm{NaCl}$ solution with fraction IV-1 is shown. Observe that trimethyl or ethyl substituted compounds (Octimet and Cetab) are less reactive than dimethyl benzyl substituted compounds (Octab and Cetylon). Albumin and gamma globulin fail to precipitate under these conditions. it will be seen that the use of $1.0 \mathrm{mg}$. of Octab for assay of alpha 1 and alpha 2 globulins permits an accurate determination of this fraction in human serum. In abnormal sera where large increments of alpha 1 and alpha 2 are present with a concomitant depression of albumin and a relative decrease of gamma globulin, the alpha globulins are determined with accuracy. Thus, while it appears that a constant ratio of cationic detergent to alpha 1 and alpha 2 globulins is desirable, such a ratio is not critical when these globulins are present in a complex protein mixture such as exists in serum.

Effect of different cationic detergents on protein precipitation. Four chemically different cationic detergents have been investigated for their reaction with different protein fractions. Octab (octadecyl dimethyl benzyl ammonium chloride) and Cetylon (cetyl dimethyl benzyl ammonium chloride) have identical effects on protein precipitation. They can be used interchangeably for assay of the three protein fractions studied. Octimet (octadecyl dimethyl ethyl ammonium chloride) and Cetab (cetyl trimethyl ammonium chloride) have less effect on protein precipitation. This is shown in Figure 5 where the reaction of fraction IV-1 at $\mathrm{pH} 7.3$ and $0.08 \mathrm{M} \mathrm{NaCl}$ is depicted. While a linear relationship between density and 
protein concentration exists for each class of detergent, the two with the trimethyl or ethyl substituted groups have a less steep slope than results from the use of the dimethyl benzyl substituted compounds.

If one adds a dimethyl benzyl substituted detergent to a mixture of protein combined with a trimethyl detergent, an increase in precipitation results. Addition of more trimethyl substituted detergent to such a mixture causes no increase in density. Thus, of these four detergents investigated, a long carbon chain substituted with a dimethyl benzyl side chain is more effectively combined with protein than is the trimethyl or ethyl substituted compound.

A chemical analogue of the cationic detergents which lacks the hydrocarbon chain was prepared. This substance $p$, $p^{\prime}$ methylene-bis $\left(\mathrm{N}_{1} \mathrm{~N}\right.$-trimethyl aniline) dichloride was added to various protein fractions in solutions with a range of $\mathrm{pH}$ from 5.0 to 12.0. No precipitation occurred. Octab was then added to samples to which $\mathrm{p}$, $\mathrm{p}$ 'methylenebis ( $\mathrm{N}_{1} \mathrm{~N}$-trimethyl aniline) dichloride had been previously added and to a control sample. The amount of turbidity developing in each sample was identical. These data suggest that $p, p^{\prime}$ methylenebis $\left(\mathrm{N}_{1} \mathrm{~N}\right.$-trimethyl aniline) dichloride neither precipitates nor blocks the precipitation of proteins after addition of a cationic detergent.

If the cationic detergents exert only a physical effect on proteins to produce turbidity it should be possible to remove the detergent by dialysis. Since a 1.0 percent solution of Octab dialyzes through a cellophane membrane, the following experiment was made.

Gamma globulin was treated in the usual manner by precipitation at $\mathrm{pH} 9.6$ with Octab. After standing, the flocculent material was removed and re-suspended in acetate buffer of $\mathrm{pH}$ 4.5. The precipitate readily redissolved and the clear solution was subjected to dialysis in a cellophane membrane against a $0.05 \mathrm{M}$ acetate buffer at $\mathrm{pH} 4.5$ for 96 hours at $4^{\circ} \mathrm{C}$. Frequent changes of the dialyzing fluid were made during this period. The gamma globulin solution was then brought to $\mathrm{pH}$ 9.6 by slow addition of $0.1 \mathrm{~N} \mathrm{NaOH}$ solution. It again developed turbidity. Such a solution similarly dialyzed and reconstituted in a solution of $\mathrm{pH} 7.0$ and with 0.9 percent $\mathrm{NaCl}$ produces hemolysis of erythrocytes which are readily he-

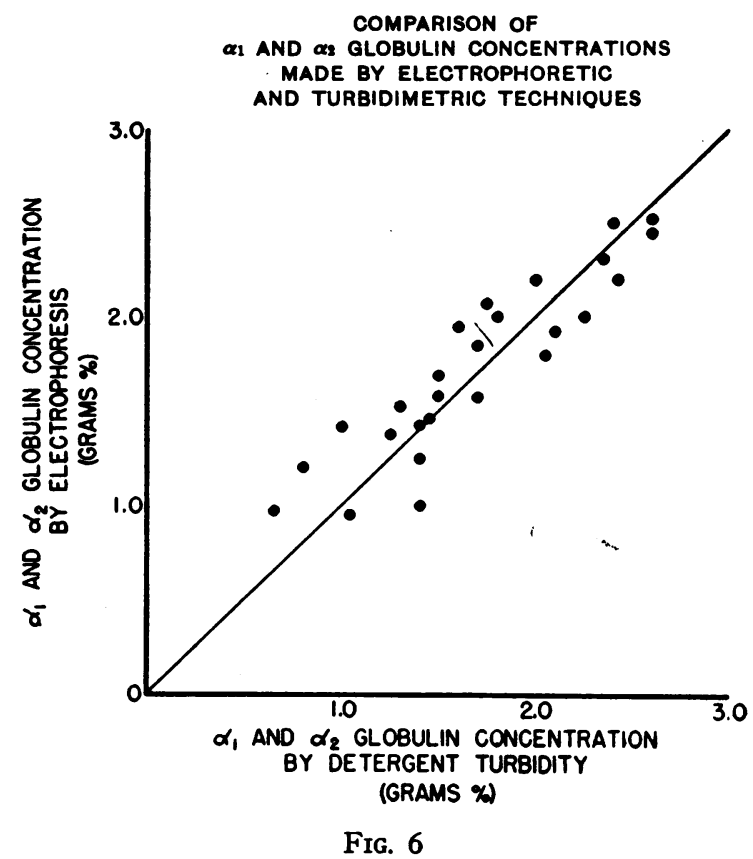

Comparison of the electrophoretic and detergent turbidimetric techniques for assay of alpha 1 and alpha 2 globulin fractions in serum. The value obtained by electrophoresis (ordinate) is plotted against the value obtained turbidimetrically on the same sample (abscissa). A line of perfect correlation is drawn to orient these comparative results.

molyzed with small amounts of Octab. Thus it appears that little if any cationic detergent was removed by dialysis.

Comparative assay of serum proteins by electrophoretic and cationic detergent methods. To determine the reliability of the cationic detergent assay technique in complex protein mixtures such as human sera, parallel studies were made utilizing Tiselius electrophoresis of serum in veronal buffer at $\mathrm{pH}$ 8.5. Sera were obtained from patients with such diverse diseases as pneumonia, tuberculosis, cirrhosis of the liver, and so forth. Forty to fifty millilitres of blood were withdrawn and allowed to clot. After centrifugation, the serum was removed and one portion was assayed for the three protein fractions as described above. The remainder of the serum was then suitably prepared and subjected to electrophoresis (6).

A comparison of the two techniques for measurement of the alpha 1 and alpha 2 globulin concentration is shown in Figure 6. Electrophoretic values (ordinate) are plotted for each serum against the corresponding detergent turbidity value 


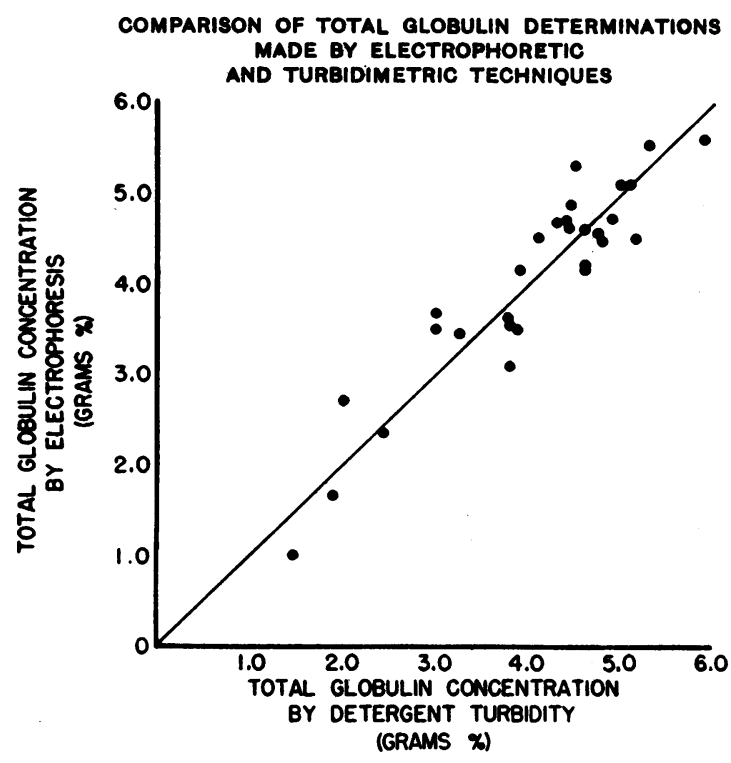

Fig. 7

Comparison of the electrophoretic and detergent turbidimetric techniques for assay of total globulin concentration in serum. Results are plotted in the same manner as in Figure 6.

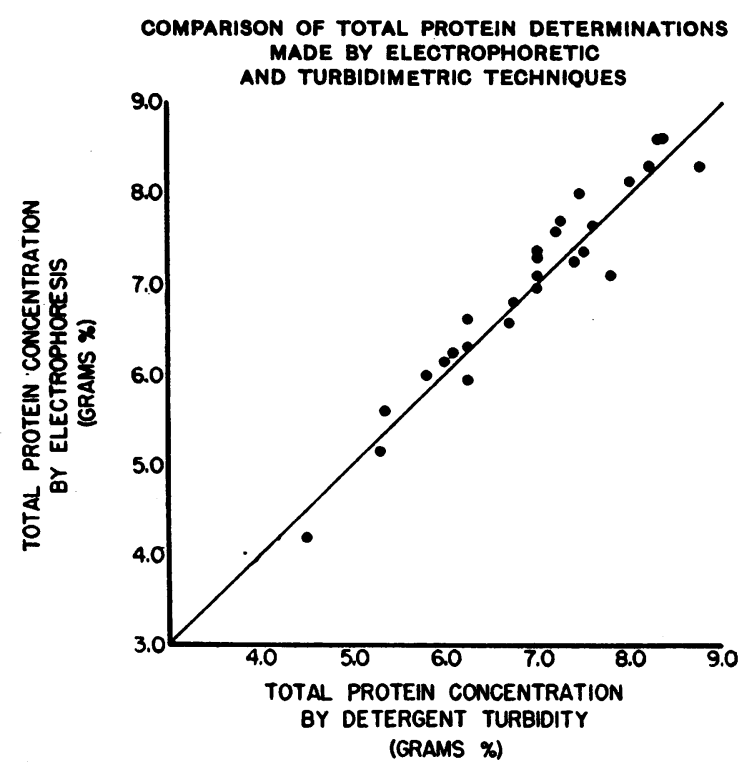

FIG. 8

Comparison of the total protein concentration obtained by electrophoretic and detergent turbidimetric techniques. Results are plotted in the same manner as in Figure 6.

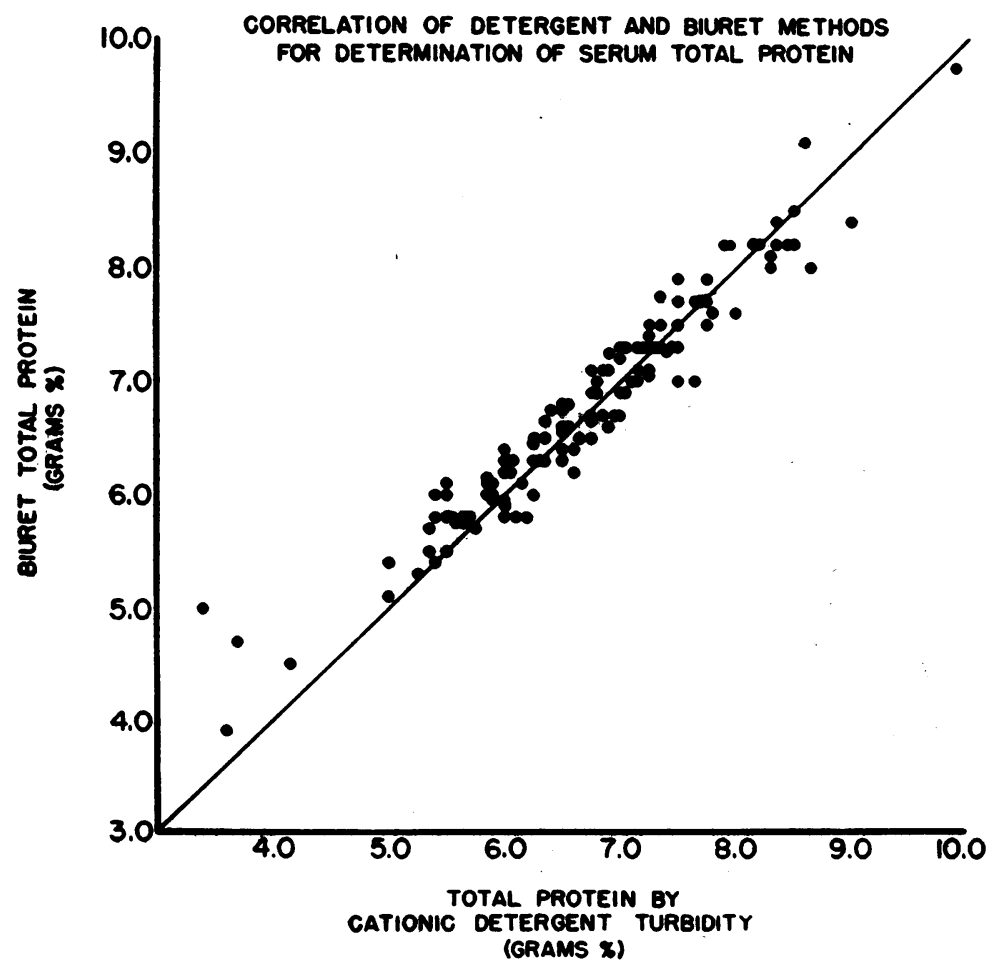

Fig. 9

Comparison of the biuret and detergent turbidimetric techniques for assay of total protein concentration in serum. Results are plotted in the same manner as in Figure 6. 


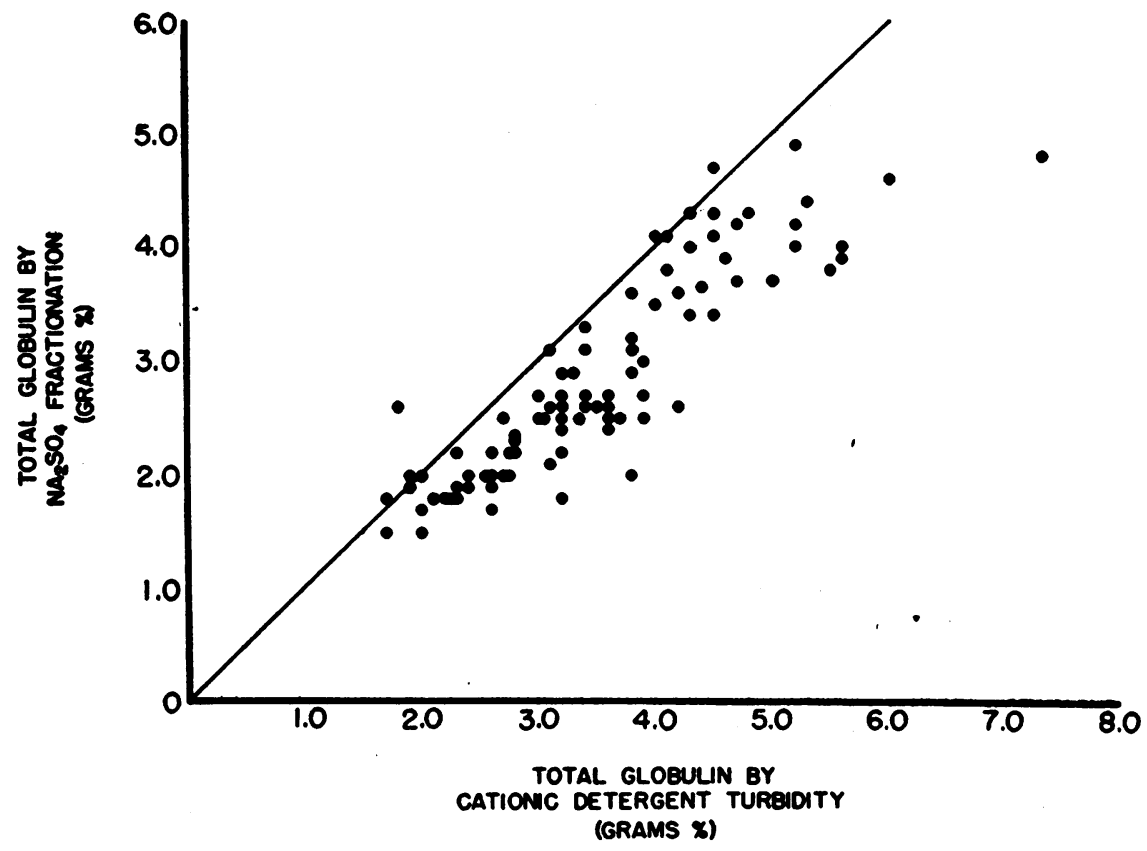

FIG. 10

Comparison of the 22.5 percent $\mathrm{Na}_{2} \mathrm{SO}_{4}$ precipitation technique with detergent turbidimetric technique for assay of serum total globulin. Observe that, utilizing the latter method, higher concentrations of globulin are consistently found.

(abscissa). A line of absolute correlation is drawn to orient the correlations for each determination. It will be observed that all but five determinations are within $\pm 0.25 \mathrm{gm}$. of the line of absolute correlation $(r=0.99)$.

In Figure 7, similar data obtained for the concentration of total globulin by each method are shown. All but five of 29 sera assayed by the detergent and electrophoretic techniques show a variation less than $\pm 0.5 \mathrm{gm}$. of the value obtained by electrophoresis $(r=0.70)$.

The data obtained for assay of the total protein concentration is similarly shown in Figure 8. All but three determinations were $\pm 0.5 \mathrm{gm}$. of the result obtained by electrophoresis $(r=0.73)$.

A comparison of the assay of total protein by the biuret technique (7) and the cationic detergent technique is shown in Figure 9. In 124 paired determinations on sera from patients, six detergent determinations were more than \pm 0.5 $\mathrm{gm}$. of the value obtained by the biuret method.

Assay of the total globulin was made by 22.4 percent $\mathrm{Na}_{2} \mathrm{SO}_{4}$ fractionation and subsequent biuret assay of the albumin fraction (7). Aliquots of the same serum were simultaneously analysed for total globulin by the detergent technique. It will be observed in Figure 10 that, utilizing the latter method, consistently higher values of globulin concentration were found. This result is not unexpected since it is known that $\mathrm{Na}_{2} \mathrm{SO}_{4}$ fails to produce complete separation of the globulins from albumin. Electrophoretic assay of $\mathrm{Na}_{2} \mathrm{SO}_{4}$ precipitated plasmas reveals that much of the alpha 1 and alpha 2 globulins remain with the albumin fraction (8).

Recovery of protein fractions added to normal and abnormal sera. Sera from a normal individual and from patients with profound alterations of the protein pattern were assayed by the detergent method described. Known concentrations of fractions IV-1, II and V were added to other aliquots of these sera and similarly assayed in order to determine percent of recovery of the added fractions. These data are shown in Table I. It will be observed that serum of patient N. P. has a high globulin concentration but a nearly nor- 
TABLE I

Recovery of various protein fractions added to human serum

\begin{tabular}{|c|c|c|c|c|c|c|c|c|c|c|}
\hline & \multirow{2}{*}{$\begin{array}{l}\text { Frac- } \\
\text { tion } \\
\text { added }\end{array}$} & \multicolumn{3}{|c|}{$\begin{array}{c}\text { Alpha } 1 \text { and Alpha } 2 \\
\text { globulin }\end{array}$} & \multicolumn{3}{|c|}{ Total globulin } & \multicolumn{3}{|c|}{ Total protein } \\
\hline & & Found & $\begin{array}{c}\text { Pre- } \\
\text { dicted }\end{array}$ & $\overline{\begin{array}{c}\text { \% Re- } \\
\text { covery }\end{array}}$ & Found & $\begin{array}{c}\text { Pre- } \\
\text { dicted }\end{array}$ & $\overline{\begin{array}{c}\text { \% Re- } \\
\text { covery }\end{array}}$ & Found & $\begin{array}{c}\text { Pre- } \\
\text { dicted }\end{array}$ & $\begin{array}{l}\text { \% Re- } \\
\text { covery }\end{array}$ \\
\hline $\begin{array}{l}\text { 1. Disseminated Lupus } \\
\text { Erythematosis } \\
\text { N. P. 1/14/53 }\end{array}$ & $\begin{array}{r}\text { IV-1 } \\
\text { IV-1 } \\
\text { II } \\
\text { II } \\
\mathrm{V} \\
\mathrm{V} \\
\mathrm{n} \text { alone }\end{array}$ & $\begin{array}{ll}3.8 & g \\
6.4 & \\
1.5 & \\
1.6 & \\
1.15 \\
1.2 \\
1.25\end{array}$ & $\begin{array}{l}3.3 \mathrm{~g} \\
5.35 \\
1.45 \\
1.65 \\
1.25 \\
1.25\end{array}$ & $\begin{array}{l}115 \% \\
119 \\
103 \\
97 \\
92 \\
96\end{array}$ & $\begin{array}{c}10.0 \mathrm{~g} \\
14.0 \\
10.8 \\
15.0 \\
7.9 \\
8.0 \\
7.4\end{array}$ & $\begin{array}{c}9.7 \mathrm{~g} \\
12.0 \\
11.2 \\
15.0 \\
7.4 \\
7.4\end{array}$ & $\begin{array}{c}103 \% \\
117 \\
97 \\
100 \\
107 \\
108\end{array}$ & $\begin{array}{l}13.3 \mathrm{~g} \\
16.0 \\
13.5 \\
17.0 \\
12.25 \\
15.0 \\
10.0\end{array}$ & $\begin{array}{l}13.3 \mathrm{~g} \\
16.6 \\
13.8 \\
17.6 \\
11.8 \\
13.6\end{array}$ & $\begin{array}{c}100 \% \\
96 \\
98 \\
97 \\
104 \\
110\end{array}$ \\
\hline $\begin{array}{l}\text { 2. Carcinoma of Lung } \\
\text { R.S. } 3 / 4 / 53\end{array}$ & $\begin{array}{r}\text { IV-1 } \\
\text { IV-1 } \\
\text { II } \\
\text { II } \\
\mathrm{V} \\
\mathrm{V} \\
\mathrm{n} \text { alone }\end{array}$ & $\begin{array}{l}4.7 \\
7.0 \\
2.88 \\
2.8 \\
2.6 \\
2.6 \\
2.65\end{array}$ & $\begin{array}{l}4.8 \\
6.75 \\
2.85 \\
3.05 \\
2.65 \\
2.65\end{array}$ & $\begin{array}{r}98 \\
104 \\
103 \\
98 \\
100 \\
100\end{array}$ & $\begin{array}{r}9.5 \\
11.7 \\
10.4 \\
13.8 \\
6.5 \\
6.7 \\
5.8\end{array}$ & $\begin{array}{r}8.1 \\
10.4 \\
9.6 \\
13.4 \\
5.8 \\
5.8\end{array}$ & $\begin{array}{l}117 \\
113 \\
108 \\
103 \\
112 \\
115\end{array}$ & $\begin{array}{c}9.9 \\
13.0 \\
10.25 \\
13.75 \\
8.9 \\
12.25 \\
7.0\end{array}$ & $\begin{array}{r}10.3 \\
13.6 \\
10.8 \\
14.6 \\
8.8 \\
10.6\end{array}$ & $\begin{array}{r}96 \\
96 \\
95 \\
94 \\
101 \\
115\end{array}$ \\
\hline $\begin{array}{l}\text { 3. Probable Myeloma } \\
\text { A. L. } 1 / 27 / 52\end{array}$ & $\begin{array}{r}\text { IV-1 } \\
\text { II } \\
\text { V } \\
\text { n alone }\end{array}$ & $\begin{array}{l}4.4 \\
1.3 \\
0.9 \\
0.9\end{array}$ & $\begin{array}{l}4.5 \\
1.3 \\
0.9\end{array}$ & $\begin{array}{r}98 \\
100 \\
100\end{array}$ & $\begin{array}{r}11.6 \\
12.8 \\
6.4 \\
5.9\end{array}$ & $\begin{array}{r}10.1 \\
13.3 \\
5.9\end{array}$ & $\begin{array}{r}115 \\
96 \\
108\end{array}$ & $\begin{array}{l}16.25 \\
17.0 \\
15.6 \\
10.5\end{array}$ & $\begin{array}{l}16.5 \\
17.3 \\
15.7\end{array}$ & $\begin{array}{l}98 \\
98 \\
99\end{array}$ \\
\hline $\begin{array}{l}\text { 4. Tuberculosis } \\
\text { J. M. 2/3/53 }\end{array}$ & $\begin{array}{r}\text { IV-1 } \\
\text { II } \\
\text { V } \\
\text { n alone }\end{array}$ & $\begin{array}{l}5.8 \\
2.2 \\
2.0 \\
2.0\end{array}$ & $\begin{array}{l}5.6 \\
2.4 \\
2.0\end{array}$ & $\begin{array}{r}103 \\
92 \\
100\end{array}$ & $\begin{array}{r}9.6 \\
11.6 \\
4.1 \\
4.6\end{array}$ & $\begin{array}{r}8.8 \\
12.0 \\
4.6\end{array}$ & $\begin{array}{r}109 \\
97 \\
89\end{array}$ & $\begin{array}{c}14.75 \\
14.0 \\
12.75 \\
8.7\end{array}$ & $\begin{array}{l}15.5 \\
14.7 \\
13.9\end{array}$ & $\begin{array}{l}95 \\
95 \\
92\end{array}$ \\
\hline $\begin{array}{l}\text { 5. Normal Adult } \\
\text { R. A. } 2 / 26 / 53\end{array}$ & $\begin{array}{r}\text { IV-1 } \\
\text { II } \\
\text { V } \\
\text { alone }\end{array}$ & $\begin{array}{l}2.2 \\
0.8 \\
0.7 \\
0.7\end{array}$ & $\begin{array}{l}2.1 \\
0.9 \\
0.7\end{array}$ & $\begin{array}{r}104 \\
89 \\
100\end{array}$ & $\begin{array}{l}4.2 \\
5.8 \\
2.3 \\
2.3\end{array}$ & $\begin{array}{l}3.9 \\
5.7 \\
2.3\end{array}$ & $\begin{array}{l}108 \\
102 \\
100\end{array}$ & $\begin{array}{r}9.6 \\
10.6 \\
9.8 \\
8.3\end{array}$ & $\begin{array}{l}10.5 \\
11.7 \\
10.5\end{array}$ & $\begin{array}{l}92 \\
91 \\
94\end{array}$ \\
\hline $\begin{array}{l}\text { 6. Cirrhosis of Liver } \\
\text { E. D. 2/15/53 }\end{array}$ & $\begin{array}{r}\text { IV-1 } \\
\text { II } \\
\mathbf{V} \\
\text { n alone }\end{array}$ & $\begin{array}{l}3.2 \\
1.95 \\
1.65 \\
1.65\end{array}$ & $\begin{array}{l}3.05 \\
1.85 \\
1.65\end{array}$ & $\begin{array}{l}106 \\
101 \\
100\end{array}$ & $\begin{array}{l}7.9 \\
9.2 \\
5.7 \\
5.6\end{array}$ & $\begin{array}{l}7.2 \\
9.0 \\
5.6\end{array}$ & $\begin{array}{l}110 \\
102 \\
102\end{array}$ & $\begin{array}{r}12.4 \\
13.2 \\
11.8 \\
9.0\end{array}$ & $\begin{array}{l}11.3 \\
12.4 \\
11.6\end{array}$ & $\begin{array}{l}108 \\
106 \\
102\end{array}$ \\
\hline $\begin{array}{l}\text { 7. Convalescent Rheu- } \\
\text { matic Fever } \\
\text { J. L. } 2 / 23 / 53\end{array}$ & $\begin{array}{r}\text { IV-1 } \\
\text { II } \\
V \\
\text { alone }\end{array}$ & $\begin{array}{l}2.8 \\
1.45 \\
1.1 \\
1.15\end{array}$ & $\begin{array}{l}2.55 \\
1.35 \\
1.15\end{array}$ & $\begin{array}{r}109 \\
107 \\
99\end{array}$ & $\begin{array}{l}5.1 \\
6.4 \\
3.4 \\
3.35\end{array}$ & $\begin{array}{l}4.95 \\
6.75 \\
3.35\end{array}$ & $\begin{array}{r}103 \\
96 \\
101\end{array}$ & $\begin{array}{r}9.8 \\
11.2 \\
10.9 \\
7.3\end{array}$ & $\begin{array}{r}9.6 \\
10.7 \\
9.9\end{array}$ & $\begin{array}{l}102 \\
104 \\
110\end{array}$ \\
\hline $\begin{array}{l}\text { 8. Rheumatoid Arthritis } \\
\text { G. U. } 2 / 19 / 53\end{array}$ & $\begin{array}{r}\text { IV-1 } \\
\text { II } \\
\text { V } \\
\text { n alone }\end{array}$ & $\begin{array}{l}3.4 \\
2.0 \\
1.85 \\
1.85\end{array}$ & $\begin{array}{l}3.35 \\
2.05 \\
1.85\end{array}$ & $\begin{array}{l}101 \\
100 \\
100\end{array}$ & $\begin{array}{l}5.4 \\
6.9 \\
3.7 \\
3.65\end{array}$ & $\begin{array}{l}5.25 \\
7.05 \\
3.65\end{array}$ & $\begin{array}{r}103 \\
98 \\
101\end{array}$ & $\begin{array}{r}9.4 \\
11.0 \\
10.0 \\
8.1\end{array}$ & $\begin{array}{l}10.4 \\
11.5 \\
10.7\end{array}$ & $\begin{array}{l}91 \\
96 \\
94\end{array}$ \\
\hline $\begin{array}{l}\text { 9. High Fever of Unknow } \\
\text { Etiology } \\
\text { W. D. 2/14/53 }\end{array}$ & $\begin{array}{r}\text { IV-1 } \\
\text { II } \\
\text { alone }\end{array}$ & $\begin{array}{l}5.5 \\
3.7 \\
3.4 \\
3.4\end{array}$ & $\begin{array}{l}5.4 \\
3.6 \\
3.4\end{array}$ & $\begin{array}{l}102 \\
103 \\
100\end{array}$ & $\begin{array}{l}7.0 \\
7.6 \\
4.8 \\
4.8\end{array}$ & $\begin{array}{l}6.4 \\
7.8 \\
4.8\end{array}$ & $\begin{array}{r}109 \\
98 \\
100\end{array}$ & $\begin{array}{l}8.6 \\
9.0 \\
7.4 \\
5.9\end{array}$ & $\begin{array}{l}8.8 \\
9.25 \\
8.5\end{array}$ & $\begin{array}{l}98 \\
98 \\
87\end{array}$ \\
\hline $\begin{array}{l}\text { 10. Normal Adult } \\
\text { W. O'B. } 2 / 23 / 53\end{array}$ & $\begin{array}{r}\text { IV-1 } \\
\text { II } \\
\text { a } \\
\text { alone }\end{array}$ & $\begin{array}{l}2.2 \\
0.9 \\
0.8 \\
0.85\end{array}$ & $\begin{array}{l}2.25 \\
1.05 \\
0.85\end{array}$ & $\begin{array}{l}98 \\
86 \\
95\end{array}$ & $\begin{array}{l}4.1 \\
5.6 \\
2.4 \\
2.5\end{array}$ & $\begin{array}{l}4.1 \\
5.9 \\
2.5\end{array}$ & $\begin{array}{r}100 \\
95 \\
96\end{array}$ & $\begin{array}{r}10.0 \\
10.8 \\
9.8 \\
7.4\end{array}$ & $\begin{array}{r}9.6 \\
10.8 \\
10.0\end{array}$ & $\begin{array}{r}104 \\
100 \\
98\end{array}$ \\
\hline $\begin{array}{l}\text { 11. Multiple Myeloma } \\
\text { F. K. 12/12/51 }\end{array}$ & $\begin{array}{r}I V-1 \\
\text { II } \\
V \\
\text { alone }\end{array}$ & $\begin{array}{r}10.7 \\
9.0 \\
8.4 \\
8.6\end{array}$ & $\begin{array}{c}10.65 \\
8.85 \\
8.6\end{array}$ & $\begin{array}{r}100 \\
102 \\
98\end{array}$ & $\begin{array}{l}16.4 \\
16.6 \\
13.8 \\
12.2\end{array}$ & $\begin{array}{l}13.8 \\
16.0 \\
12.2\end{array}$ & $\begin{array}{l}119 \\
104 \\
112\end{array}$ & $\begin{array}{l}15.4 \\
15.8 \\
15.0 \\
13.3\end{array}$ & $\begin{array}{l}16.6 \\
17.1 \\
15.1\end{array}$ & $\begin{array}{l}93 \\
92 \\
99\end{array}$ \\
\hline $\begin{array}{l}\text { 12. Nephrosis } \\
\text { W. B. } 1 / 4 / 52\end{array}$ & $\begin{array}{r}\text { IV-1 } \\
\text { II } \\
V \\
\text { alone }\end{array}$ & $\begin{array}{l}4.9 \\
4.4 \\
3.25 \\
3.2\end{array}$ & $\begin{array}{l}5.25 \\
3.45 \\
3.2\end{array}$ & $\begin{array}{r}93 \\
122 \\
102\end{array}$ & $\begin{array}{l}6.0 \\
7.9 \\
3.8 \\
3.9\end{array}$ & $\begin{array}{l}5.5 \\
7.7 \\
3.9\end{array}$ & $\begin{array}{r}109 \\
103 \\
97\end{array}$ & $\begin{array}{l}7.3 \\
7.4 \\
6.5 \\
4.1\end{array}$ & $\begin{array}{l}7.4 \\
7.9 \\
5.9\end{array}$ & $\begin{array}{r}99 \\
94 \\
110\end{array}$ \\
\hline
\end{tabular}

Known amounts of fractions IV-1, II or $\mathrm{V}$ were added to different sera. A particular serum and the same serum with the added fraction were then assayed by the cationic detergent technique. The predicted values shown were calculated by addition of the serum value to the value obtained for the particular fraction added. 
mal alpha globulin concentration. When two different concentrations of fractions IV-1, II and albumin are added to this serum, 92 to 119 percent recovery of the added protein is accomplished.

The serum of patient R. S., with a metastatic carcinoma of the lung, has a high alpha globulin concentration as well as an increase in the beta and gamma globulin fraction (3.15 gm.). Recovery of added aliquots of fraction IV-1, II and albumin to this serum ranges between 94 to 117 percent.

Patient F. K. is of particular interest, since she had extensive myelomatosis. By electrophoresis, about 60 percent of the total protein migrated in the gamma globulin position. There was little increase in the alpha globulins yet detergent assay reveals a concentration of $8.6 \mathrm{gm}$. This value represents an extreme elevation and when it is of this magnitude, is diagnostic of multiple myeloma (9). In this instance, there is a marked discrepancy between the detergent assay and the electrophoretic determination. Such a discrepancy is not found in all patients with multiple myeloma studied so far, indicating that only certain myeloma proteins react with a cationic detergent in the $\mathrm{pH}$ range of the alpha globulins (9). Despite the abnormal behavior of the gamma migrating myeloma protein, recovery of added fraction IV-1, II and albumin is good.

In patient $\mathrm{W}$. B. with profound serum protein alterations secondary to nephrosis, again, good recovery of added protein fractions is obtained.

\section{DISCUSSION}

This investigation of the interaction of the alpha globulins, gamma globulin and albumin with cationic detergents permits three conclusions to be made. First, the magnitude of turbidity produced by the interaction of detergent and protein, as influenced by the hydrogen ion concentration, cannot be related to the isoelectric point of the proteins investigated. Secondly, none of these proteins produce turbidity with a cationic detergent in any range of $\mathrm{pH}$ unless $\mathrm{NaCl}$ or some similar salt is present in the reaction. In general, an increase in the $\mathrm{NaCl}$ concentration causes a proportional increase in turbidity with a cationic detergent when the reaction is carried out at $\mathrm{pH} 9.6$ or 12.0 . How- ever, the reaction of gamma globulin at $\mathrm{pH} 9.6$ differs from that of the alpha globulins and albumin in that an increase of salt concentration beyond $0.12 \mathrm{M}$ causes a decrease in turbidity. Finally, the amount of turbidity formed by the interaction of these proteins and the cationic detergents is governed by the molecular configuration of the radicals attached to the hydrocarbon chain. Thus, maximal turbidity develops for a dimethyl benzyl substituted compound, while a trimethyl or ethyl substitution results in a less active interaction of detergent and protein. When a non-hydrocarbon cationic substance, p,p'methylene-bis $\left(\mathrm{N}_{1} \mathrm{~N}\right.$-trimethyl aniline) dichloride is used, neither protein precipitation nor inhibition of precipitation by one of the hydrocarbon cationic detergents results.

It must be recognized that these experiments have not established that turbidity is actually a good measure of protein precipitation. It is possible that the effect of $\mathrm{NaCl}$ in particular may not be so much an enhancement of the interaction of protein and detergent but that it may exert some influence upon the size of the agglutinating particles which in turn influence the turbidity of the solution.

There is considerable speculation but little is known about the mode of reaction of anionic detergents with proteins (5). Even less is known about the reaction of cationic detergents with proteins. Under suitable conditions, most, if not all, soluble protein fractions precipitate at or just below their isoelectric points with the anionic detergents (10). In the case of the cationic detergents, it is apparent in a study of albumin in particular, that precipitation occurs at a point considerably beyond the known isoelectric point. Thus it seems likely that cationic detergents may react with proteins by a different mechanism than do the anionic analogues.

The evidence gained by an investigation of the effect of dialysis of the protein and detergent complex and the effects of non-hydrocarbon cationic substance such as p,p'methylene-bis $\left(\mathrm{N}_{1} \mathrm{~N}\right.$-trimethyl aniline) dichloride in neither precipitating nor blocking the cationic detergent effect, does not permit a definitive conclusion regarding the mode of reaction of these detergents with proteins. One can speculate that carboxyl or sulfhydryl groups may combine with the ammonium cationic charges 
and effect subsequent precipitation. If one extends such an hypothesis further, one might consider that the alpha globulins have more of these groups reactive at a low $\mathrm{pH}$, while albumin requires a marked decrease in the hydrogen ion concentration before these groups become accessible for interaction with the cationic detergent.

It is apparent that the present data do not allow any reasonable conclusion to be formulated to explain the reaction of cationic detergents with the various human protein fractions under the experimental conditions described. However, a practical advantage of these observations is found when an application of these principles is made in a study of protein mixtures. Thus, utilizing the partitioning effect of a cationic detergent such as Octab, with the $\mathrm{pH}$ and salt concentration suitably controlled, it is possible to assay with considerable accuracy the alpha globulins, total globulin and the total protein concentration of human serum. Previous work had indicated that qualitative assay might be accomplished $(2,11,12)$. The comparative studies of sera by means of electrophoresis and by means of recovery experiments, confirm the specificity of cationic detergent action under an established buffer-salt set-up for each protein fraction.

The use of such an assay technique in clinical medicine has several advantages. Since considerable dilution of serum is required for an optimal detergent interaction with the protein fractions, as little as $0.05 \mathrm{ml}$. of serum can be employed for an analysis of all fractions. Thus, capillary blood can be used. Secondly, after the preliminary preparation of the buffer solutions and the standard curves, nearly the same information found by Tiselius electrophoresis can be obtained with less effort, utilizing this detergent method. Such a procedure permits a more exhaustive study of protein metabolic alterations in disease and has contributed particularly in investigations of the globulin alterations seen in acute rheumatic fever (2), cirrhosis of the liver (9), and other disease states $(9,12)$.

The plasma protein alterations found in patients with multiple myeloma and in certain types of hepatic disease, produce markedly discrepant results when the electrophoretic and detergent techniques are compared. Further investigation of these divergent findings may reveal additional information concerning the known abnormal character of the myeloma proteins and the beta protein described.

\section{SUMMARY}

1. An investigation of the interaction of cationic detergents with three protein fractions, fraction IV-1, fraction II and albumin has been described. The differential effect of $\mathrm{pH}$, salt concentration and molecular configuration of the cationic detergent on protein precipitation is shown.

2. An application of these observations to a differential quantitative fractionation of human serum has been made. By comparative studies with electrophoresis and by recovery experiments, it is shown that assay of the alpha globulins, the beta and gamma fraction, albumin and the total protein can be made with accuracy, utilizing the cationic detergent technique described.

\section{ACKNOWLEDGMENT}

Grateful acknowledgment is made to the following: Dr. Eric Alling for the Tiselius electrophoretic determinations reported and for many helpful suggestions made during the course of the investigation; Dr. John Lambooy, who supplied the p,p'methylene-bis $\left(\mathrm{N}_{1} \mathrm{~N}\right.$-trimethyl aniline) dichloride; Mrs. Gloria Cushing and Miss Hildegarde Muhlnickel, whose technical assistance was invaluable.

\section{REFERENCES}

1. Jacox, R. F., The reaction of human serum and component proteins of human plasma with a quaternary ammonium salt, Octab. J. Lab. \& Clin. Med., 1951, 37, 721.

2. Jacox, R. F., and Gale, R. G., The reaction of human serum with a quaternary ammonium salt: Results of a serial study in acute rheumatic fever. J. Lab. \& Clin. Med., 1951, 37, 728.

3. Gomori, G., Buffers in the range of $\mathrm{pH} 6.5$ to 9.6 . Proc. Soc. Exper. Biol. \& Med., 1946, 62, 33.

4. Zeldis, L. J., Alling, E. L., McCoord, A. B., and Kulka, J. P., Plasma protein metabolism-electrophoretic studies: The influence of plasma lipids on electrophoretic patterns of human and dog plasma. J. Exper. Med., 1945, 82, 411.

5. Putnam, F. W., The interactions of proteins and synthetic detergents. Advances in Protein Chemistry, 1948, 4, 79.

6. Zeldis, L. J., and Alling, E. L., Plasma protein metabolism-electrophoretic studies: Restoration of cir- 
culating proteins following acute depletion by plasmapheresis. J. Exper. Med., 1945, 81, 515.

7. Gornall, A. G., Bardawill, C. J., and David, M. M., Determination of serum proteins by means of the biuret reaction. J. Biol. Chem., 1949, 177, 751.

8. Gutman, A. B., The plasma proteins in disease. Advances in Protein Chemistry, 1948, 4, 155.

9. Jacox, R. F., Unpublished observations.

10. Alling, E. L., Unpublished observations.

11. Loomeijer, F. J., Fractionation of serum proteins with a quaternary ammonium detergent. Nature, 1950, 166, 951.

12. a) Mayer, R. L., and Eisman, P. C., Precipitation patterns of normal and pathologic blood sera with cationic detergents. Proc. Soc. Exper. Biol. \& Med., 1951, 77, 452.

b) Bronfin, G. J., Hart, R. W., Liebler, J. B., and Goldner, M. G., Precipitation of blood sera with a cationic detergent. A clinical evaluation. Proc. Soc. Exper. Biol. \& Med., 1951, 77, 456. 